\title{
Quantifying lithogenic inputs to the North Pacific Ocean using the long-lived thorium isotopes
}

\author{
Christopher T. Hayes ${ }^{a, b, *}$, Robert F. Anderson ${ }^{a, b}$, Martin Q. Fleisher ${ }^{a}$, Sascha Serno ${ }^{a, c}$, \\ Gisela Winckler ${ }^{\mathrm{a}, \mathrm{b}}$, Rainer Gersonde ${ }^{\mathrm{d}}$ \\ a Lamont-Doherty Earth Observatory of Columbia University, Palisades, NY, USA \\ b Department of Earth and Environmental Sciences, Columbia University, New York, NY, USA \\ c DFG-Leibniz Center for Surface Process and Climate Studies, Institute of Earth and Environmental Science, University of Potsdam, Potsdam-Golm, Germany \\ d Alfred Wegener Institute for Polar and Marine Research, Bremerhaven, Germany
}

\section{A R T I C L E I N F O}

\section{Article history:}

Received 12 April 2013

Received in revised form 11 September

2013

Accepted 13 September 2013

Available online $\mathrm{xxxx}$

Editor: G. Henderson

\section{Keywords:}

dust

aerosols

thorium

boundary exchange

North Pacific Ocean

GEOTRACES compliant

\begin{abstract}
A B S T R A C T
Dissolved ${ }^{232} \mathrm{Th}$ is added to the ocean though the partial dissolution of lithogenic materials such as aerosol dust in the same way as other lithogenically sourced and more biologically important trace metals such as Fe. Oceanic ${ }^{230} \mathrm{Th}$, on the other hand, is sourced primarily from the highly predictable decay of dissolved ${ }^{234} \mathrm{U}$. The rate at which dissolved ${ }^{232} \mathrm{Th}$ is released by mineral dissolution can be constrained by a Th removal rate derived from ${ }^{230} \mathrm{Th}:{ }^{234} \mathrm{U}$ disequilibria, assuming steady-state. Calculated fluxes of dissolved ${ }^{232} \mathrm{Th}$ can in turn be used to estimate fluxes of other lithogenically sourced dissolved metals as well as the original lithogenic supplies, such as aerosol dust deposition, given the concentration and fractional solubility of Th (or other metals) in the lithogenic material. This method is applied to 7 water column profiles from the Innovative North Pacific Experiment (INOPEX) cruise of 2009 and 2 sites from the subtropical North Pacific. The structure of shallow depth profiles suggests rapid scavenging at the surface and at least partial regeneration of dissolved ${ }^{232} \mathrm{Th}$ at $100-200 \mathrm{~m}$ depth. This rapid cycling could involve colloidal Th generated during mineral dissolution, which may not be subject to the same removal rates as the more truly dissolved ${ }^{230} \mathrm{Th}$. An additional deep source of ${ }^{232} \mathrm{Th}$ was revealed in deep waters, most likely dissolution of seafloor sediments, and offers a constraint on dissolved trace element supply due to boundary exchange.
\end{abstract}

(c) 2013 Elsevier B.V. All rights reserved.

\section{Introduction}

The ocean is the ultimate receptor of eroded material from the continents. In the remote surface ocean, this process occurs only through deposition of eolian mineral dust (referred to also as aerosol dust or simply as dust) (Rea, 1994) and in some cases dust is a dominant source of soluble micronutrients necessary for biological productivity (Martin and Gordon, 1988). Quantification of aerosol dust input to the surface ocean has progressed in recent years using a combination of remote sensing and modeling techniques (Mahowald et al., 2005), but these models nonetheless are better constrained with observational tracer-based approaches using, for instance, dissolved Al (Measures and Brown, 1996) and more recently dissolved Th (Hsieh et al., 2011). The partial dissolution of hemipelagic sediments, or more generally, margin sediment exchange processes, may also contribute to the ocean budget of

\footnotetext{
* Corresponding author. Present address: Massachusetts Institute of Technology, Department of Earth, Atmospheric and Planetary Sciences, 45 Carleton St., E25-610, Cambridge, MA 02139, USA. Tel.: +1 617253 5733; fax: +1 6172538630 .

E-mail address: cthayes@mit.edu (C.T. Hayes).
}

dissolved trace metals of paleoceanographic interest such as $\mathrm{Nd}$ (Lacan and Jeandel, 2005), Hf (van de Flierdt et al., 2004), as well as ${ }^{232}$ Th (Roy-Barman, 2009). The importance of boundary exchange processes has been difficult to assess because knowledge of the rates involved in the biogeochemical cycle of these elements is lacking.

The long-lived thorium isotopes $\left({ }^{232} \mathrm{Th}\right.$ and ${ }^{230} \mathrm{Th}$ : half-lives, 14.01 Ga (Holden, 1990) and 75.69 ka (Cheng et al., 2000), respectively) offer a way to determine rates of lithogenic element cycling in seawater. The shorter-lived, ${ }^{230} \mathrm{Th}$, is radiogenic, with a well-quantified source from ${ }^{234} \mathrm{U}$ dissolved in seawater. To determine ${ }^{230}$ Th production, ${ }^{234} \mathrm{U}$ concentrations are estimated using measured salinity and published estimates of the salinity-U relationship in North Pacific seawater (Chen et al., 1986) and the seawater ${ }^{234} U /{ }^{238} U$ ratio (Andersen et al., 2010). More than 99.8\% of Th in seawater, however, is ${ }^{232} \mathrm{Th}$, a primordial isotope added to seawater in the dissolved pool through the partial dissolution of lithogenic materials (Santschi et al., 2006). Thorium (and therefore all Th isotopes) is highly insoluble in seawater and is rapidly removed from solution by scavenging onto particulate matter (Moore and Sackett, 1964). 


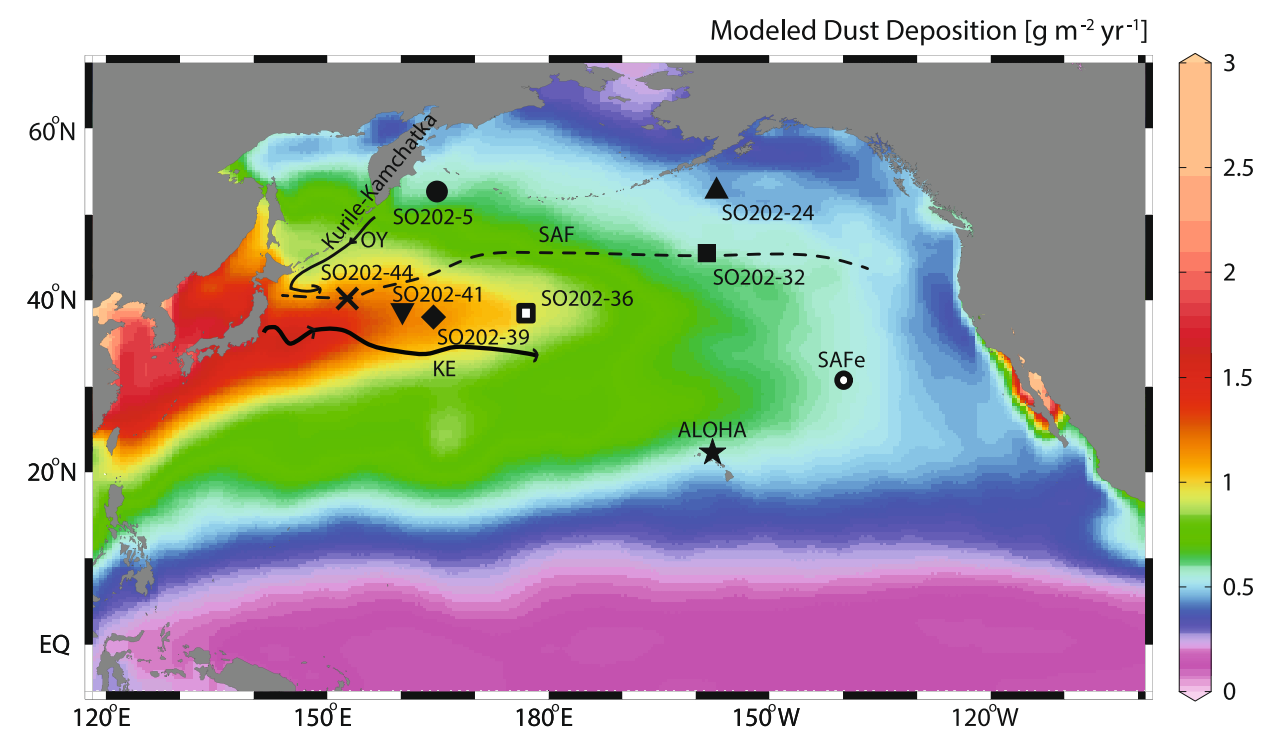

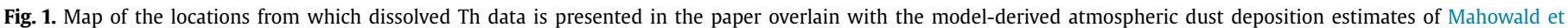

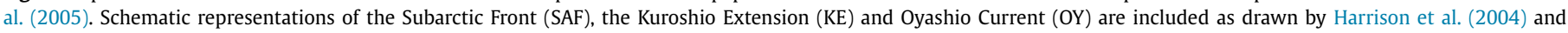
Chen (2008).

The rate of Th removal by scavenging, equivalent to the inverse of the Th residence time, $\tau_{\mathrm{Th}}$, can be quantified using measurements of dissolved ${ }^{230} \mathrm{Th}$, assuming steady-state against production by uranium decay. Production of ${ }^{230} \mathrm{Th}$ is given by the activity of ${ }^{234} \mathrm{U}$ (in units concordant with the ${ }^{230} \mathrm{Th}$ units) multiplied by the radioactive decay rate of ${ }^{230} \mathrm{Th}, \lambda_{230}$. We take inventories of both ${ }^{230} \mathrm{Th}$ and its production due to ${ }^{234} \mathrm{U}$ decay to calculate residence time as a function of integrated depth (Eq. (1a)). This residence time is applied to the integrated inventory of dissolved ${ }^{232} \mathrm{Th}$ to estimate the cumulative flux of ${ }^{232} \mathrm{Th}$ due to mineral dissolution (Hirose and Sugimura, 1987), from the surface to depth, $z$. A concentration, $\left[{ }^{232} \mathrm{Th}\right]_{\text {litho, }}$, and fractional solubility, $S_{\mathrm{Th}}$, of Th in the lithogenic material can then be used to estimate the flux of lithogenic material which produced the observed dissolved inventory (Eq. (1b)), as described by Hsieh et al. (2011). In the surface of the open ocean, this lithogenic flux is generally assumed to be dissolution of aerosol dust, but near ocean margins, including the seafloor, an apparent lithogenic flux could arise from the partial dissolution of hemipelagic or resuspended pelagic sediments.

$\tau_{\mathrm{Th}}(z)=\frac{\int_{0}^{z} \text { dissolved }{ }^{230} \mathrm{Th} d z}{\int_{0}^{z} \text { activity }{ }^{234} \mathrm{U} * \lambda_{230} d z}$

Lithogenic flux $(z)=\frac{\int_{0}^{z} \text { dissolved }{ }^{232} \mathrm{Th} d z}{\tau_{\mathrm{Th}}(z) \times\left[{ }^{232} \mathrm{Th}\right]_{\text {litho }} \times S_{\mathrm{Th}}}$

$$
=\frac{\text { Dissolved }{ }^{232} \mathrm{Th} \text { flux }(z)}{\left[{ }^{232} \mathrm{Th}\right]_{\text {litho }} \times S_{\mathrm{Th}}}
$$

Using depth profiles of dissolved ${ }^{230} \mathrm{Th}$ and ${ }^{232} \mathrm{Th}$ from the North Pacific, this study aims to: (1) quantify dust deposition at sites under the influence of the Asian dust plume, (2) critically evaluate the paired-Th isotope method for lithogenic fluxes in seawater, and (3) use deep water ${ }^{232}$ Th fluxes to demonstrate a deep source of dissolved ${ }^{232} \mathrm{Th}$, with implications for boundary exchange.

\section{Materials and methods}

Sampling for dissolved $(<0.45 \mu \mathrm{m}){ }^{232} \mathrm{Th}$ and ${ }^{230} \mathrm{Th}$ took place at seven locations (Fig. 1) during the SO202-INOPEX cruise of July-August 2009 (Gersonde, 2012). In this manuscript, Th, ${ }^{232} \mathrm{Th}$ and ${ }^{230} \mathrm{Th}$ refer to the dissolved phase unless otherwise noted.
Sampling and analysis of thorium isotopes were carried out by GEOTRACES-compliant (intercalibrated) methods (www.geotraces. org), described fully by Anderson et al. (2012).

Four-to-five liter water samples were analyzed in batches of $10-12$. Procedural blanks were determined by processing 4-5 L of Milli-Q water in an acid-cleaned cubitainer acidified to $\mathrm{pH} \sim 2$ with $6 \mathrm{M} \mathrm{HCl}$ as a sample in each batch. For a measure of reproducibility, an aliquot of an intercalibrated working standard solution of dissolved ${ }^{232} \mathrm{Th}$ and ${ }^{230} \mathrm{Th}$, SW-STD 2010-1 referred to by Anderson et al. (2012), was added to a separate cubitainer with $5 \mathrm{~L}$ of Milli-Q water (acidified to $\mathrm{pH} 2$ ) and also processed like a sample in each batch. Total procedural blanks were $7.1-24.3 \mathrm{pg}$ ${ }^{232} \mathrm{Th}$ and $0.8-1.6 \mathrm{fg}{ }^{230} \mathrm{Th}$. These blanks are equivalent to $3-30 \%$ and $1-20 \%$ of the measured seawater ${ }^{232} \mathrm{Th}$ and ${ }^{230} \mathrm{Th}$ signals. Reproducibility of the ${ }^{232} \mathrm{Th}(\sim 990 \mathrm{pg} / \mathrm{g})$ and ${ }^{230} \mathrm{Th}(\sim 250 \mathrm{fg} / \mathrm{g})$ concentrations in SW-STD 2010-1 over several years has been $4.7 \%$ and $1.3 \%$, respectively.

Concentrations of ${ }^{230} \mathrm{Th}$ were corrected for in-growth due to uranium decay during sample storage (1-2 years). In order to use ${ }^{230} \mathrm{Th}:{ }^{234} \mathrm{U}$ disequilibrium to derive a Th residence time, ${ }^{230} \mathrm{Th}$ concentrations must also be corrected for a proportion of ${ }^{230} \mathrm{Th}$ released by the dissolution of lithogenic materials. This is based on concurrent measurements of ${ }^{232} \mathrm{Th}$, assuming a lithogenic ratio ${ }^{230} \mathrm{Th} /{ }^{232} \mathrm{Th}=4.0 \times 10^{-6} \mathrm{~mol} / \mathrm{mol}$ (Roy-Barman et al., 2009). Our INOPEX results and complete method descriptions are available at PANGAEA (http://doi.pangaea.de/10.1594/PANGAEA.811760) and BCO-DMO (http://osprey.bcodmo.org/dataset.cfm?id=14254\&flag= view).

\section{Results and discussion}

\subsection{Shallow dissolved ${ }^{230} \mathrm{Th}^{232} \mathrm{Th}$ profiles}

The INOPEX depth profiles of ${ }^{230} \mathrm{Th}$ are discussed in detail elsewhere (Hayes et al., 2013). The observed near-linear increases in concentration with depth (Fig. 2) reflect the effects of reversible scavenging (Bacon and Anderson, 1982) whereby ${ }^{230} \mathrm{Th}$, produced uniformly in the water column, is concentrated at depth through cycles of adsorption and desorption with sinking particles. This behavior, especially in the upper $1000 \mathrm{~m}$, has been observed in almost all other ${ }^{230} \mathrm{Th}$ profiles from the region (Nozaki et al., 1981, 1987; Nozaki and Nakanishi, 1985; Roy-Barman et al., 1996). 


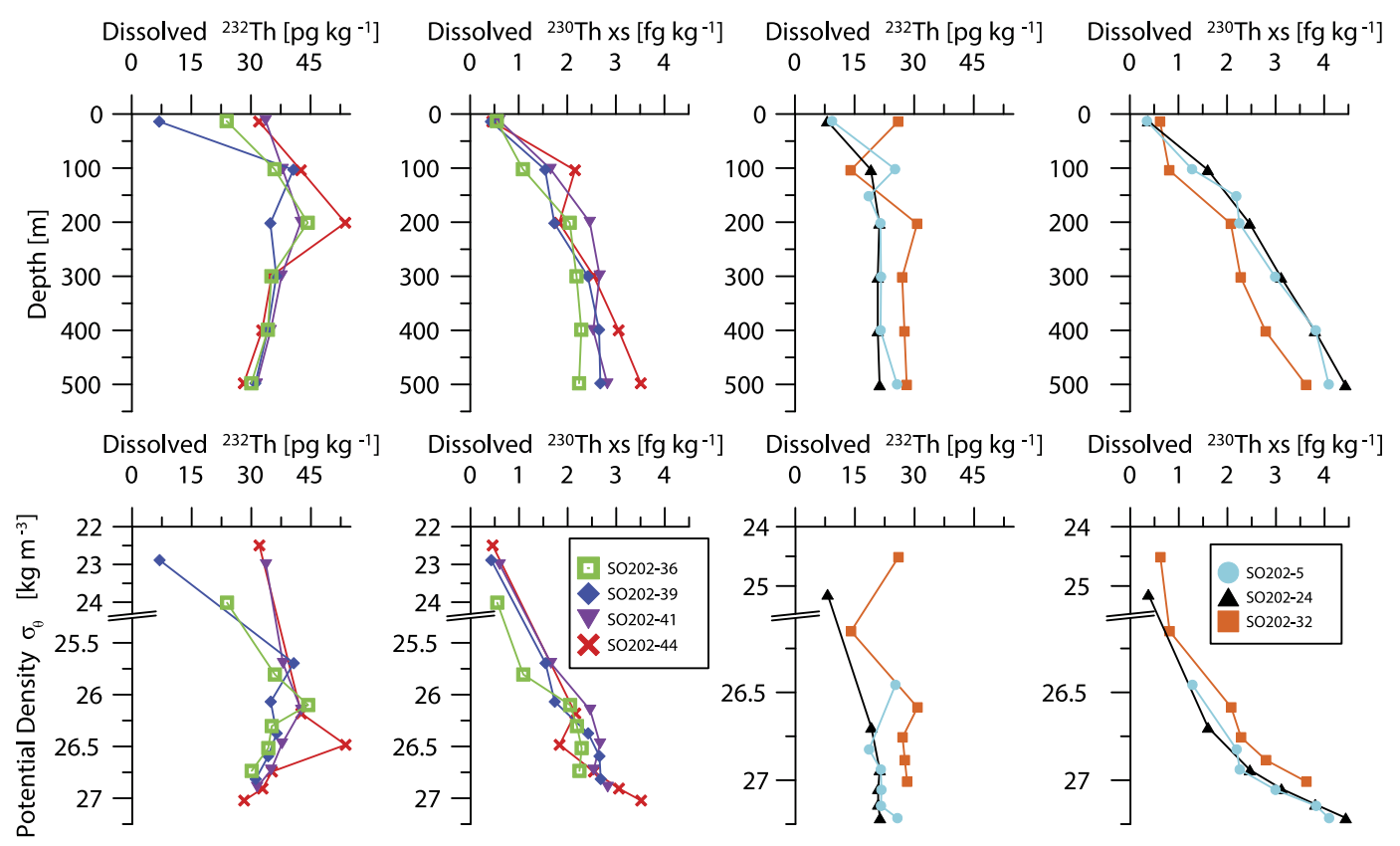

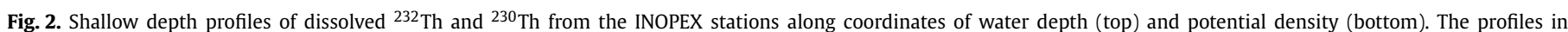

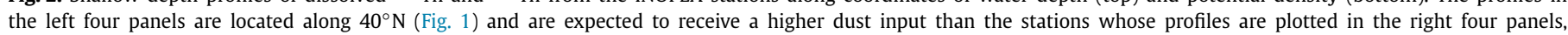
according to the Mahowald et al. (2005) model.
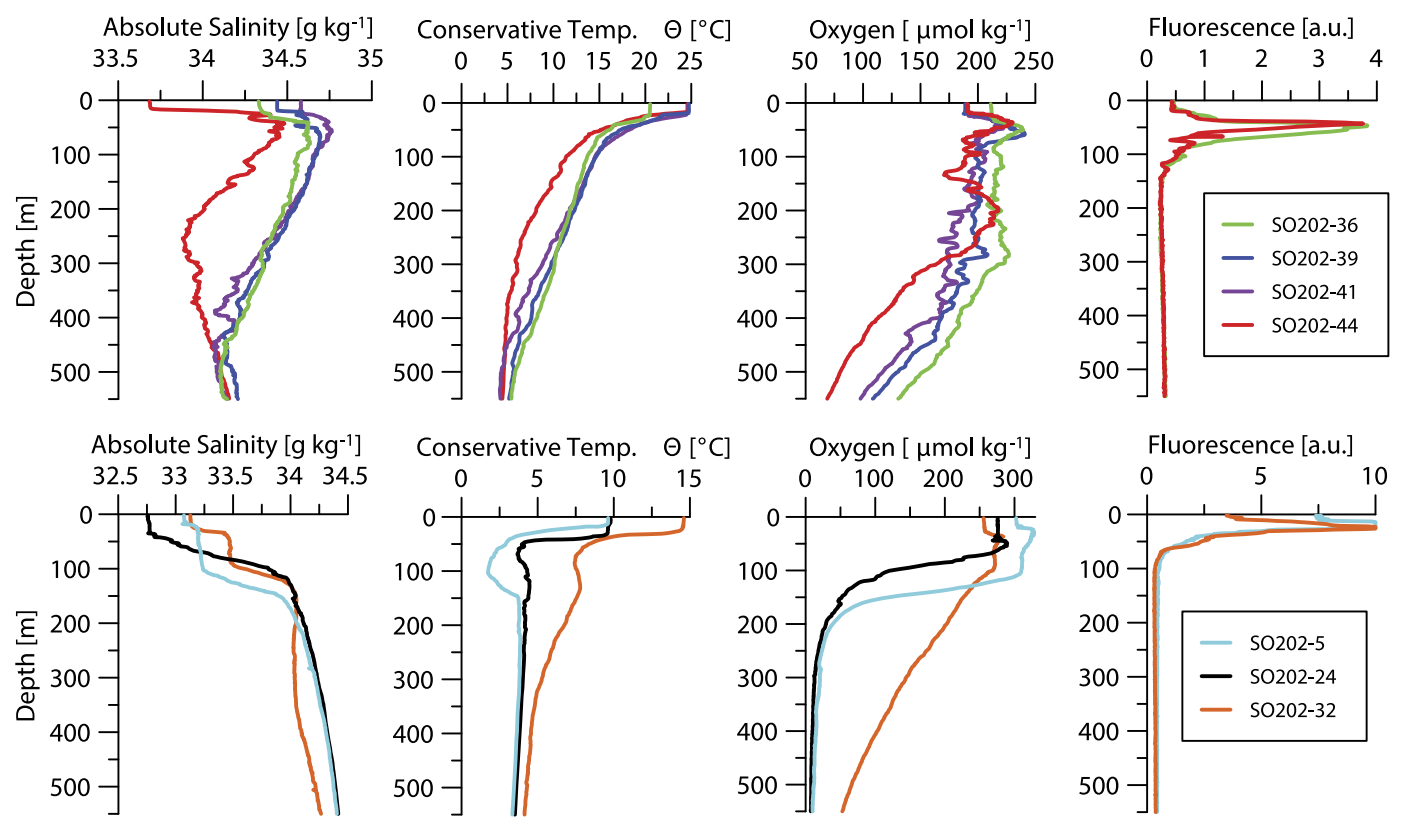

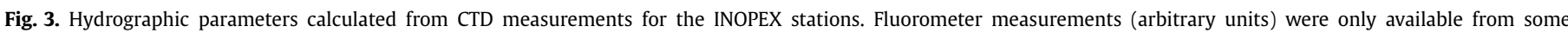
stations.

Our results for ${ }^{232} \mathrm{Th}$ are more novel. At each of the seven INOPEX sites, most noticeably at the 4 stations near $40^{\circ} \mathrm{N}$, where we expect the highest dust input (Fig. 1) (Mahowald et al., 2005), ${ }^{232} \mathrm{Th}$ increases in concentration with depth from $10 \mathrm{~m}$ (within the mixed layer) to a local subsurface maximum between $100-200 \mathrm{~m}$ depth (Fig. 2). These well-defined subsurface maxima in ${ }^{232} \mathrm{Th}$ lead us to discuss three possible explanations which are important in evaluating the paired-Th isotope method for lithogenic supplies: (1) lateral advection or eddy-diffusion of ${ }^{232} \mathrm{Th}$ at the subsurface maxima, (2) seasonality of eolian- ${ }^{232} \mathrm{Th}$ deposition, and (3) non-steady-state Th scavenging and regeneration dynamics.

\subsubsection{Hydrographic influences}

The subsurface ${ }^{232} \mathrm{Th}$ maxima could in principle reflect an advective/diffusive input, for instance, of water recently in contact with detrital sediment. This influence is addressed in two ways: hydrographic context (Fig. 3) and advective-diffusive scaling arguments in comparison to Th residence times. Each station was observed with a warm, fresh and shallow (17-35 m, Table 1) mixed layer, typical of summertime in the subarctic Pacific (Ohno et al., 2009). The mixed layer depth criterion is a $0.125 \mathrm{~kg} \mathrm{~m}^{-3}$ change in potential density with respect to the surface (Levitus, 1982; Suga et al., 2004). The North Pacific mixed layer has great seasonal variability, however, with much deeper mixed layers in win- 
Table 1

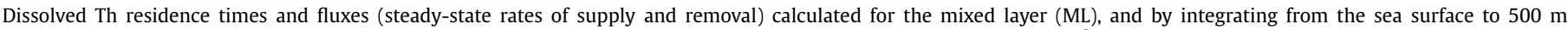

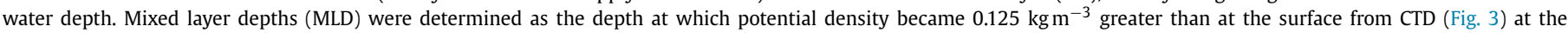
time of sampling.

\begin{tabular}{|c|c|c|c|c|c|}
\hline Station & $\begin{array}{l}\text { MLD }^{\mathrm{a}} \\
(\mathrm{m})\end{array}$ & $\begin{array}{l}\tau_{\mathrm{Th}} \\
\text { (ML, yrs) }\end{array}$ & $\begin{array}{l}\tau_{\mathrm{Th}} \\
(500 \mathrm{~m}, \mathrm{yrs})\end{array}$ & $\begin{array}{l}{ }^{232} \text { Th flux } \\
\left(\mathrm{ML}, \mu \mathrm{g} \mathrm{m}^{-2} \mathrm{yr}^{-1}\right)\end{array}$ & $\begin{array}{l}{ }^{232} \text { Th flux } \\
\left(500 \mathrm{~m}, \mu \mathrm{g} \mathrm{m}^{-2} \mathrm{yr}^{-1}\right)\end{array}$ \\
\hline SO202-5 & 18 & $0.7 \pm 0.3$ & $4.7 \pm 0.1$ & $0.33 \pm 0.07$ & $2.26 \pm 0.07$ \\
\hline SO202-24 & 35 & $0.7 \pm 0.2$ & $4.9 \pm 0.1$ & $0.52 \pm 0.04$ & $2.00 \pm 0.05$ \\
\hline SO202-32 & 26 & $1.2 \pm 0.2$ & $3.7 \pm 0.1$ & $0.82 \pm 0.05$ & $3.50 \pm 0.10$ \\
\hline SO202-36 & 24 & $1.0 \pm 0.3$ & $3.3 \pm 0.1$ & $0.76 \pm 0.10$ & $5.48 \pm 0.23$ \\
\hline SO202-39 & 19 & $0.8 \pm 0.3$ & $3.6 \pm 0.1$ & $0.24 \pm 0.05$ & $4.64 \pm 0.16$ \\
\hline SO202-41 & 22 & $1.1 \pm 0.3$ & $4.0 \pm 0.1$ & $0.84 \pm 0.10$ & $4.74 \pm 0.15$ \\
\hline SO202-44 & 17 & $0.8 \pm 0.3$ & $4.2 \pm 0.1$ & $0.92 \pm 0.16$ & $4.70 \pm 0.14$ \\
\hline ALOHA & $50^{\mathrm{b}}$ & $2.2 \pm 1.3$ & $6.4 \pm 1.2$ & $0.34 \pm 0.06$ & $1.06 \pm 0.26$ \\
\hline SAFe & 15 & $2.2 \pm 0.5$ & $5.2 \pm 0.4$ & $0.12 \pm 0.03$ & $1.03 \pm 0.09$ \\
\hline
\end{tabular}

a MLD in the region of SO202 stations is highly seasonal. Data here was collected in late summer while winter mixed layers can exceed 200 $\mathrm{m}$ (see Section 3.1.2).

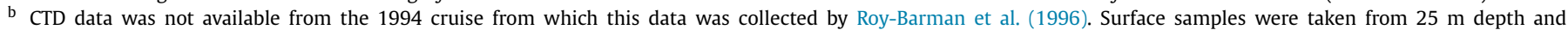
noted to be within the mixed layer. We chose $50 \mathrm{~m}$ mixed layer based on climatology (Church et al., 2013).

ter. In particular, in the western North Pacific between $30-45^{\circ} \mathrm{N}$, mixed layer depths can often exceed $200 \mathrm{~m}$ (Ohno et al., 2009; Oka et al., 2007).

These deep mixed layers lead to the formation of various mode waters. North Pacific Subtropical Mode Water (STMW, $\sigma_{\theta}=$ 25.0-25.7 $\mathrm{kg} \mathrm{m}^{-3}$ ) (Bingham, 1992; Hanawa and Suga, 1995), known to be enriched in Al (Measures et al., 2005), outcrops or forms south of the Kuroshio Extension (generally south of $36^{\circ} \mathrm{N}$, Fig. 1) (Chen, 2008; Oka et al., 2007). STMW is therefore not likely to influence the INOPEX sites (north of $38^{\circ} \mathrm{N}$ ), although there is the possibility for cross frontal mixing in this region of high eddy kinetic energy (Ducet et al., 2000).

North Pacific Central Mode Water (CMW, $\sigma_{\theta}=25.9-26.5$ $\mathrm{kg} \mathrm{m}^{-3}$ ) and Transition Region Mode Water (TRMW, $\sigma_{\theta}=26.4-$ $26.6 \mathrm{~kg} \mathrm{~m}^{-3}$ ) form from the deep winter mixed layers north of the Kuroshio Extension and south of the Subarctic Front (Hanawa and Talley, 2001; Oka et al., 2011), encompassing the region of stations SO202-36 through -44 (Fig. 1). The subsurface ${ }^{232}$ Th maxima (at SO202-36 through -44) occur in the potential density layers, $\sigma_{\theta}=25.7-26.5 \mathrm{~kg} \mathrm{~m}^{-3}$ (Fig. 2), overlapping with CMW and TRMW. These mode waters could receive detrital trace metal inputs from the Kuril-Kamchatka margin and/or the Okhotsk Sea via the Oyashio Current (Morton, 2010).

In the case of SO202-44, the subsurface ${ }^{232} \mathrm{Th}$ maximum coincides with a slight intrusion of higher $\mathrm{O}_{2}$ waters (Fig. 3), indicative of a recently ventilated mode water (Measures et al., 2006) and suggestive that this station may be partially influenced by detritally enriched CMW. North Pacific Intermediate Water (NPIW), which also forms near the subarctic boundary is notable in our profiles as a salinity minimum at $250-500 \mathrm{~m}$ depth, $\sigma_{\theta}=26.8 \mathrm{~kg} \mathrm{~m}^{-3}$ (Talley, 1993). NPIW, however, is below the subsurface peaks in ${ }^{232} \mathrm{Th}$. While we cannot rule out lateral transport processes based on hydrography alone, we now consider the timescales necessary for lateral transport.

Ocean dispersion transports non-conservative elements if the transport processes occur on a timescale shorter than the residence time of the element. The Th residence time in the upper $500 \mathrm{~m}$ (Table 1 ) at the INOPEX sites is $3-5$ years. We expect horizontal eddy diffusivity, $K_{\mathrm{H}}$, at a typical rate of $10^{3} \mathrm{~m}^{2} \mathrm{~s}^{-1}$ (Kawabe, 2008), to reach roughly $500 \mathrm{~km}$ lateral extent within that timescale ( $\Delta x=\sqrt{2 K_{\mathrm{H}} \tau_{\mathrm{Th}}}$, parameterizing eddy diffusivity as a random-walk process). Station SO202-5 is $312 \mathrm{~km}$ from the Kamchatka margin and SO202-24 is $310 \mathrm{~km}$ from the nearest Aleutian coast, and therefore these stations will be influenced by any strong Th sources at those coasts by eddy-diffusion alone. Station SO202-44 is $850 \mathrm{~km}$ from the Japanese margin. This is longer than our estimated diffusion length but does not necessarily imply the station is isolated from coastal input. Rather the diffusion length is an e-folding length, meaning any coastal to open concentration dif- ference in ${ }^{232} \mathrm{Th}$ will be reduced by 2.71 over that distance. Additionally, advective processes will occur on even faster timescales and over longer distances.

Drifter floats suggest eastward ocean velocities at $\sim 500 \mathrm{~m}$ depth in the region of SO202-44 on the order of $1 \mathrm{~cm} / \mathrm{s}$ (Iwao et al., 2003). Thus advection could carry a Th signal from the Japanese margin to SO202-44 in as little as 2.7 yrs, less than the $500-\mathrm{m}$ Th residence time. Nonetheless, the similarity of the ${ }^{232} \mathrm{Th}$ profiles at SO202-36 through -44 argues against this possibility as one would expect attenuation of an advective signal with distance from the source. Stations SO202-32, -36, -39 and -41 are $>1100 \mathrm{~km}$ ( $>3.5$ yrs travel time for a $1 \mathrm{~cm} / \mathrm{s}$ current) from any coast and are much less likely to be influenced by coastal sources of Th.

We cannot rule out the influence of coastal input, or lateral sources in general, from observations of ${ }^{232} \mathrm{Th} /{ }^{230} \mathrm{Th}$ alone. In future studies we suggest combined measurements of Th isotopes and ${ }^{228} \mathrm{Ra}$. This isotope builds up in coastal water in contact with sediments, which contain its parent, ${ }^{232}$ Th (Moore, 2000). The halflife of ${ }^{228} \mathrm{Ra}(5.75 \mathrm{yr}$ ) is similar to the residence time of Th in surface waters. Thus it is well suited to trace offshore transport on relevant timescales. The rapid attenuation of the ratio of ${ }^{228} \mathrm{Ra}$ to the long-lived ${ }^{226} \mathrm{Ra}$ (half-life of $1600 \mathrm{yrs}$ ) within $\sim 300 \mathrm{~km}$ of the coast of Fukushima, Japan (Charette et al., 2013) suggests, therefore, that a significant fraction of coastal Th will not be transported offshore much further than this. Nevertheless, paired measurements of offshore gradients in ${ }^{228} \mathrm{Ra}$ and ${ }^{232} \mathrm{Th}$ are recommended for future studies to better constrain potential sedimentary sources of ${ }^{232} \mathrm{Th}$.

\subsubsection{Seasonality}

The deposition of Asian dust over the North Pacific occurs seasonally, the strongest events happening in spring (Duce et al., 1980). This phenomenon has been documented through decadal time-series measurements of aerosol-Al (Parrington et al., 1983) and Fe (Johnson et al., 2003) in Hawaii, and aerosol- ${ }^{232} \mathrm{Th}$ in Japan (Hirose et al., 2012). Variability in dissolved Fe in surface waters at ALOHA station (Fig. 1) has also been attributed to spring dust events (Boyle et al., 2005). Since the INOPEX samples were collected in July-August 2009, a time of low aerosol index (http://toms.gsfc.nasa.gov/) in the North Pacific, typical of the summer season, we need to account for how the seasonality of aerosol- ${ }^{232}$ Th input affects our observations. This is done in light of our ${ }^{230} \mathrm{Th}$-based Th residence times.

The Th residence times calculated for the mixed layer at the INOPEX stations are all roughly $1 \mathrm{yr}$ (Table 1 ). This reflects an apparent uniformity in scavenging removal of Th in the subarctic Pacific (Hayes et al., 2013). To contrast the subarctic Pacific with an environment of much lower scavenging intensity, we calculate Th residence times in surface waters using the ${ }^{230} \mathrm{Th}-{ }^{232} \mathrm{Th}$ data 
available from the subtropical North Pacific (Anderson et al., 2012; Roy-Barman et al., 1996). The SAFe station was occupied in May 2009 and ALOHA was occupied in September 1994 for the data used here (see Fig. 1 for locations). Dissolved ${ }^{230}$ Th concentrations from SAFe and ALOHA have been corrected for storage in-growth and lithogenic inputs. CTD data was not available from the Sept. 1994-ALOHA cruise, so we have assumed a $50 \mathrm{~m}$ mixed layer based on climatology (Church et al., 2013). The subtropical sites have a mixed layer Th residence time of $\sim 2$ yrs (Table 1 ).

In both the subarctic and subtropical North Pacific regions, where mixed layer Th residence times are 1-2 yrs, seasonal ${ }^{232} \mathrm{Th}$ inputs can be expected to result in muted seasonal changes in ${ }^{232}$ Th concentrations. Additionally, we would also expect changes in surface ${ }^{230} \mathrm{Th}$ concentration due to short-term (weeks-months) scavenging events to be muted by the filter of a 1-2 yrs running average. However, Th residence times based on mixed layer ${ }^{230} \mathrm{Th}$ can be overestimated because of upwelling and vertical mixing of higher ${ }^{230} \mathrm{Th}$-water from below (Luo et al., 1995). Strong seasonal variations in the surface water ${ }^{234} \mathrm{Th}$ from time-series studies in the northwestern North Pacific (Kawakami and Honda, 2007) and at ALOHA (Benitez-Nelson et al., 2001) also argue that a year-long mixed layer Th residence time is an overestimate. In fact, a disconcerting result of applying ${ }^{230} \mathrm{Th}$-based residence times to ${ }^{232} \mathrm{Th}$ inventories in the mixed layer is an anomalously low ${ }^{232} \mathrm{Th}$ flux at SO202-39 because of an anomalously low ${ }^{232}$ Th concentration in the mixed layer there (Table 1, Fig. 2), while one would expect consistent flux results for the proximal INOPEX stations in an annually-smoothed average. Based on the available data, it is not clear whether mixed-layer ${ }^{230} \mathrm{Th}$ and ${ }^{232} \mathrm{Th}$ concentrations will be sensitive to seasonality or if this is a limitation of using the longerlived ${ }^{230} \mathrm{Th}$ to document intra-annual changes. Future time-series measurements should seek to elucidate this point.

\subsubsection{Thorium cycling}

Given the uncertainties in interpreting the mixed layer ${ }^{230} \mathrm{Th}-$ ${ }^{232} \mathrm{Th}$ results, we investigate how ${ }^{232} \mathrm{Th}$ fluxes change as one integrates deeper into the water column, and therefore over a longer timescale. As described in Section $1,{ }^{230} \mathrm{Th}$ production due to ${ }^{234} \mathrm{U}$ decay, as well as ${ }^{230} \mathrm{Th}$ and ${ }^{232} \mathrm{Th}$ inventories, are all integrated with depth to produce a residence time and flux that is representative of the water column between the surface and the chosen depth of integration. To fully capture the subsurface ${ }^{232} \mathrm{Th}$ maxima, we choose to integrate to $500 \mathrm{~m}$ depth. While by integrating deeper into the water column we lose information about shorter timescales which may be of interest, it reduces the potential uncertainty in Th residence times due to vertical redistribution of ${ }^{230} \mathrm{Th}$, accounts for seasonal variations in mixed layer depth and particle cycling, and produces more geographically-consistent ${ }^{232}$ Th fluxes (Table 1). Compared to the mixed layer calculations, Th residence times over $500 \mathrm{~m}$ depth increase by a factor of 2-7 (implying slower Th removal), while ${ }^{232}$ Th fluxes increase by a factor of 3-20. In other words, ${ }^{232} \mathrm{Th}$ inventories increase with depth by more than is expected by the decrease in removal rate associated with a larger integrated water column.

Increased flux with integration depth could be an artifact of vertical mixing, which by causing an overestimation of the mixed layer ${ }^{230} \mathrm{Th}$ residence time could cause the mixed layer ${ }^{232} \mathrm{Th}$ flux to be underestimated (Eq. (1b)). To estimate upward flux of ${ }^{230} \mathrm{Th}$ by mixing, we calculate the vertical ${ }^{230} \mathrm{Th}$ concentration gradient across the mixed layer (between 10 and $100 \mathrm{~m}$ ) and multiply by a vertical mixing coefficient $\left(K_{\mathrm{v}}\right)$. For surface waters in this region, we use $K_{\mathrm{v}}=10^{-5} \mathrm{~m}^{2} \mathrm{~s}^{-1}$, as determined by Charette et al. (2013). The resultant upward flux of ${ }^{230}$ Th by vertical mixing $\left(K_{\mathrm{v}} * d^{230} \mathrm{Th} / d z\right)$ for the INOPEX stations is $5-60 \%$ of in-situ production of ${ }^{230} \mathrm{Th}$ in the mixed layer. Thus, our Th residence times may be overestimated by a factor of $1.05-2.5$, and consequently the mixed layer ${ }^{232}$ Th fluxes may be underestimated by the same factor. While the true $K_{\mathrm{v}}$ at these sites may have been $>10^{-5} \mathrm{~m}^{2} \mathrm{~s}^{-1}$, this effect is most likely not a large enough to explain the relative increase in observed ${ }^{232} \mathrm{Th}$ fluxes when integrating to $500 \mathrm{~m}$.

Similarly, vertical mixing can represent a supply or removal term for ${ }^{232} \mathrm{Th}$ in the mixed layer. Following an approach like that described above for ${ }^{230} \mathrm{Th}$, for each station we calculate a flux of ${ }^{232} \mathrm{Th}$ due to vertical mixing and compare it to the magnitude of our original estimate of mixed layer dissolved ${ }^{232}$ Th flux (Table 1). Results suggest that vertical mixing can range from a net source of ${ }^{232} \mathrm{Th}$ to the mixed layer, contributing a maximum of $50 \%$ to the calculated ${ }^{232} \mathrm{Th}$ flux at SO202-39, to a small net loss (only at SO202-32, where the concentration of ${ }^{232} \mathrm{Th}$ decreases below the mixed layer and the loss by vertical mixing represents $5 \%$ of the mixed layer ${ }^{232} \mathrm{Th}$ flux). When ${ }^{232} \mathrm{Th}$ is added to the mixed layer by vertical mixing, the calculated flux of dissolved ${ }^{232} \mathrm{Th}$ will overestimate the supply due to dust dissolution. This counteracts to some degree the underestimation of dust supply introduced by vertical mixing of ${ }^{230} \mathrm{Th}$ (see above). Therefore, we do not consider vertical mixing a significant factor in our observation of increased ${ }^{232}$ Th flux with integration depth.

Lastly, we explore the possibility that the increase with integration depth of the calculated dissolved ${ }^{232} \mathrm{Th}$ flux results from the generation of operationally defined dissolved ${ }^{232} \mathrm{Th}(<0.45 \mu \mathrm{m})$ from particulate ${ }^{232} \mathrm{Th}$ by a process that does not significantly affect the dissolved ${ }^{230} \mathrm{Th}$ distribution involving colloidal particles $(0.02-0.45 \mu \mathrm{m})$. Truly dissolved, or soluble, species are also operationally defined $(<0.02 \mu \mathrm{m})$. It has been shown in seawater leaching experiments that Fe dissolved from aerosols is dominated by the colloidal fraction (Aguilar-Islas et al., 2010) so it is reasonable to hypothesize that Th dissolves from dust as colloids as well. Each ${ }^{230} \mathrm{Th}$ atom in the ocean however is produced from a single decay event that releases it into solution. The average dissolved speciation of two Th isotopes may therefore be different, ${ }^{230}$ Th more soluble, ${ }^{232}$ Th more colloidal, because of their differing sources, with implications for their cycling in the water column. For instance, when colloidal ${ }^{232} \mathrm{Th}$ is converted into truly dissolved ${ }^{232} \mathrm{Th}$, this represents a net addition of dissolved ${ }^{232} \mathrm{Th}$ unaccounted for by the adsorption/desorption (reversible scavenging) reactions of ${ }^{230} \mathrm{Th}$.

Few data on marine colloidal ${ }^{232} \mathrm{Th} /{ }^{230} \mathrm{Th}$ exist. In two out of three samples from the Gulf of Mexico, it was found that a larger proportion of dissolved ${ }^{232} \mathrm{Th}$ existed in the colloidal phase than did the radiogenic ${ }^{234}$ Th (Baskaran et al., 1992). However, it is worth noting that Baskaran et al. (1992) could not confidently exclude ${ }^{232} \mathrm{Th}$ contamination. In contrast, Roy-Barman et al. (2002) found that the ${ }^{232} \mathrm{Th} /{ }^{230} \mathrm{Th}$ ratio did not change between dissolved $(<0.2 \mu \mathrm{m})$ and ultra-filtered $(<1 \mathrm{kDa})$ seawater from the Mediterranean Sea, suggesting similar speciation of the 2 isotopes in both colloidal and truly dissolved size-classes.

Apparently low ${ }^{232} \mathrm{Th}$ concentrations in the mixed layer (most dramatically for example at SO202-39) could be the result of rapid removal by colloidal aggregation and/or biologically-mediated particle packaging followed by the sinking of these particles, with which ${ }^{230} \mathrm{Th}$ does not equilibrate. Colloidal material has a very rapid turnover time (days to weeks) in the upper ocean (Moran and Buesseler, 1992) and laboratory experiments have shown that Th can be effectively regenerated from particles through protistan grazing (Barbeau et al., 2001). Therefore, apparently high ${ }^{232} \mathrm{Th}$ concentrations at depth (the subsurface maxima) could represent the disaggregation of those sinking particles into colloids or fully regenerated as truly dissolved $\mathrm{Th}$.

Regeneration of Th at 100-200 m depth has also been documented for the shorter-lived Th isotopes, as excess activities of ${ }^{234} \mathrm{Th}$ (Buesseler et al., 2009; Maiti et al., 2010) and ${ }^{228} \mathrm{Th}$ (Li et al., 1980; Luo et al., 1995) over their soluble parent nuclides $\left({ }^{238} \mathrm{U}\right.$ 

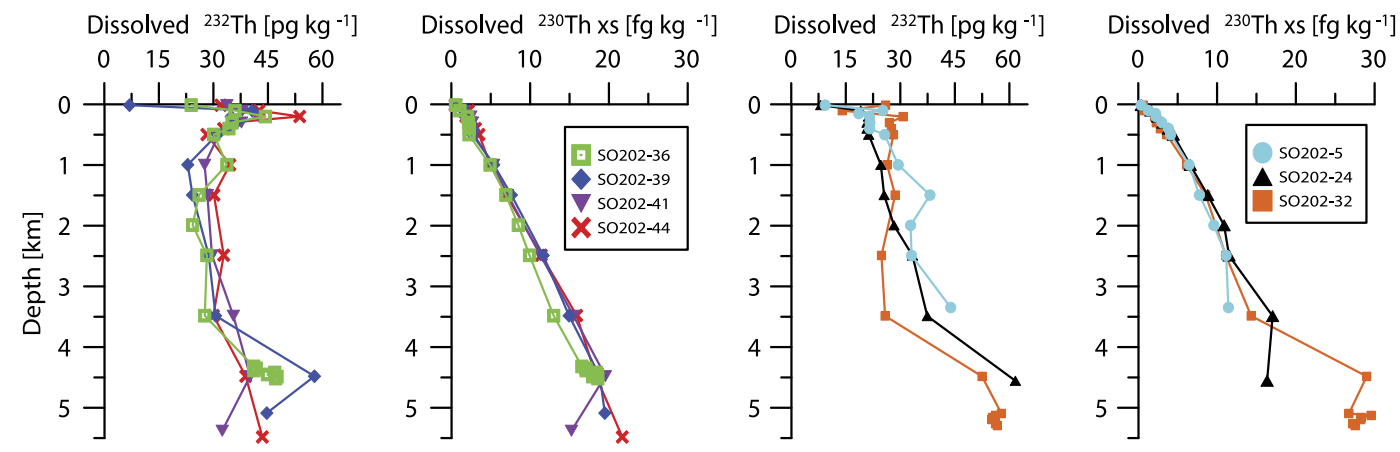

Fig. 4. Full-depth profiles of dissolved ${ }^{232} \mathrm{Th}$ and ${ }^{230} \mathrm{Th}$ from the INOPEX sites. Measurement errors are smaller than or equal to the symbol size.

and ${ }^{228} \mathrm{Ra}$, respectively). While these isotopes are also products of in-situ decay (not dust dissolution), because of their much shorter half-lives (24.1 days and 1.9 yrs, respectively), their excess activities below the euphotic zone require rapid regeneration of particulate Th.

Perhaps the shorter-lived Th isotopes can capture rapid scavenging dynamics while ${ }^{230} \mathrm{Th}$ does not. For instance, we do not observe strong evidence for regeneration at depth in the ${ }^{230} \mathrm{Th}$ profiles, considering the near-linear depth profiles of dissolved ${ }^{230}$ Th (Fig. 2). Alternatively, ${ }^{230} \mathrm{Th}$ concentration anomalies in profile may be smoothed by vertical mixing, as ${ }^{230} \mathrm{Th}$ displays larger depth gradients in concentration than the other Th isotopes. Future size-fractionated Th isotope studies in seawater will inform us about differing removal rates among the thorium isotopes (Marchal and Lam, 2012). For instance, the high depth-resolution ${ }^{234} \mathrm{Th}-{ }^{232} \mathrm{Th}-{ }^{230} \mathrm{Th}-{ }^{228} \mathrm{Th}$ data being collected by the GEOTRACES program will help test the hypothesis that each dissolved Th isotope is subject to similar removal rates. Identifying the chemical composition of the colloids important for cycling Th (e.g., lithogenic versus organic) would also be of great interest.

\subsection{Full water column ${ }^{232}$ Th profiles}

Before applying the ${ }^{232} \mathrm{Th}$ data to estimate lithogenic fluxes, it is useful to consider the full-depth distribution of ${ }^{232} \mathrm{Th}$ measured in the INOPEX region (Fig. 4). Among stations SO202-36 through -44 , the ${ }^{232}$ Th profiles show concentration maxima above $500 \mathrm{~m}$ depth, minimum concentrations at $\sim 1-3 \mathrm{~km}$ depth, and generally increasing concentrations within about $1 \mathrm{~km}$ of the seafloor. The only previously reported full-depth profile of dissolved ${ }^{232} \mathrm{Th}$ from the subarctic Pacific (north of $\left.38^{\circ} \mathrm{N}\right)$, station AN-4 $\left(39.6^{\circ} \mathrm{N}\right.$, $145.5^{\circ} \mathrm{E}$ ) (Nozaki et al., 1987), did not sample above $1 \mathrm{~km}$ depth, and showed Th concentrations 2-5 times greater (100-240 pg/kg) than those observed at SO202-44 at similar depths. This may reflect higher Th input near the Japanese coast but also could be related to differences in sampling and methodology as seawater Th analysis has progressed (Huh et al., 1989). Increasing Th concentration near the seafloor has also been found in the subtropical Pacific (Nozaki and Horibe, 1983; Okubo et al., 2012; Roy-Barman et al., 1996). The average dissolved ${ }^{232}$ Th concentration for all the INOPEX samples is $33 \mathrm{pg} / \mathrm{kg}$, higher than the average ( $15 \mathrm{pg} / \mathrm{kg}$ ) observed in the subtropical Pacific (Okubo et al., 2012; Roy-Barman et al., 1996) and tropical Pacific (Singh et al., 2013).

The "mid-depth-minimum" profile shape of the ${ }^{232} \mathrm{Th}$ profiles of SO202-32 through -44 is similar to that of $\mathrm{Al}$ in the North Pacific (Measures et al., 2005; Orians and Bruland, 1986). As Orians and Bruland (1986) pointed out for $\mathrm{Al}$, we conclude that there are two sources of Th to the ocean: one shallow due to dust dissolution and one deep associated with sediment dissolution/resuspension; and one removal mechanism, scavenging throughout the water column. At SO202-5 and SO202-24, ${ }^{232}$ Th appears to increase in concentration continuously with depth, implicating a full-depth sediment source from the nearby continental margin. Resuspension of sediments by deep currents along the Aleutian and Kurile margins (Owens and Warren, 2001) may enhance the release of dissolved ${ }^{232} \mathrm{Th}$ near the seafloor.

At all sites, the near-bottom source of dissolved ${ }^{232} \mathrm{Th}$ is most likely introduced by lateral mixing or advection along isopycnals that impinge on the seafloor where sediment resuspension/dissolution occurs. Upward mixing of dissolved ${ }^{232} \mathrm{Th}$ from the seafloor directly underlying the sampling sites is most likely too slow in comparison to lateral transport (Roy-Barman, 2009). We cannot at this time, however, directly trace the source of this deep ${ }^{232} \mathrm{Th}$ input, as sediment resuspension appears to be spatially inhomogeneous (Hayes et al., 2013; Okubo et al., 2012) and high quality data on dissolved ${ }^{232}$ Th from the North Pacific margins do not yet exist.

To further dissect the Th cycle in the North Pacific, we calculate the depth-integrated dissolved ${ }^{232} \mathrm{Th}$ flux at all depths in the INOPEX, ALOHA and SAFe profiles (Fig. 5). The ${ }^{232} \mathrm{Th}$ flux always increases rapidly with integrated depth to at least $500 \mathrm{~m}$ (Section 3.1). Excluding SO202-5 and SO202-24, which appear to receive ${ }^{232} \mathrm{Th}$ from the continental margin at all depths, the ${ }^{232} \mathrm{Th}$ fluxes do not increase greatly between $1 \mathrm{~km}$ and $3.5 \mathrm{~km}$ depth. We interpret this regular pattern to indicate that after the dissolved Th flux is generated due to dust dissolution above $1 \mathrm{~km}$ depth, little new $\mathrm{Th}$ is added in the deeper water column, until within about $1 \mathrm{~km}$ of the seafloor where the flux begins to increase again due to the bottom sediment source.

The full-depth dissolved ${ }^{232} \mathrm{Th}$ flux at the subtropical sites is 3-4 times smaller than the INOPEX sites. This likely reflects the greater aerosol- ${ }^{232} \mathrm{Th}$ input in the subarctic; however, the subarctic Pacific may also be influenced by a greater sedimentary ${ }^{232} \mathrm{Th}$ source (boundary exchange).

\subsection{Dissolved ${ }^{232}$ Th-based dust fluxes}

Because ${ }^{232} \mathrm{Th}$ fluxes change dramatically with integration depth, it is necessary to justify the depth at which depthintegrated dissolved ${ }^{232} \mathrm{Th}$ fluxes best represent input from dust. Originally we chose $500 \mathrm{~m}$ to integrate through features of the ${ }^{232}$ Th concentration profile that suggest rapid Th cycling in the upper water column. In general, the integrated ${ }^{232} \mathrm{Th}$ fluxes reach an asymptote with integration depth at $1 \mathrm{~km}$. Importantly, between $100 \mathrm{~m}$ and $1000 \mathrm{~m}$ integration depth, the relative variation between the station fluxes remains similar (Fig. 5). Therefore the exact integration depth within the zone of increasing ${ }^{232}$ Th flux may be less important than choosing a standard depth, although this will influence the apparent fractional solubility (see below). We propose to continue using $500 \mathrm{~m}$ integration as a baseline for estimating open ocean dust fluxes from dissolved ${ }^{232} \mathrm{Th}-{ }^{230} \mathrm{Th}$ data. 

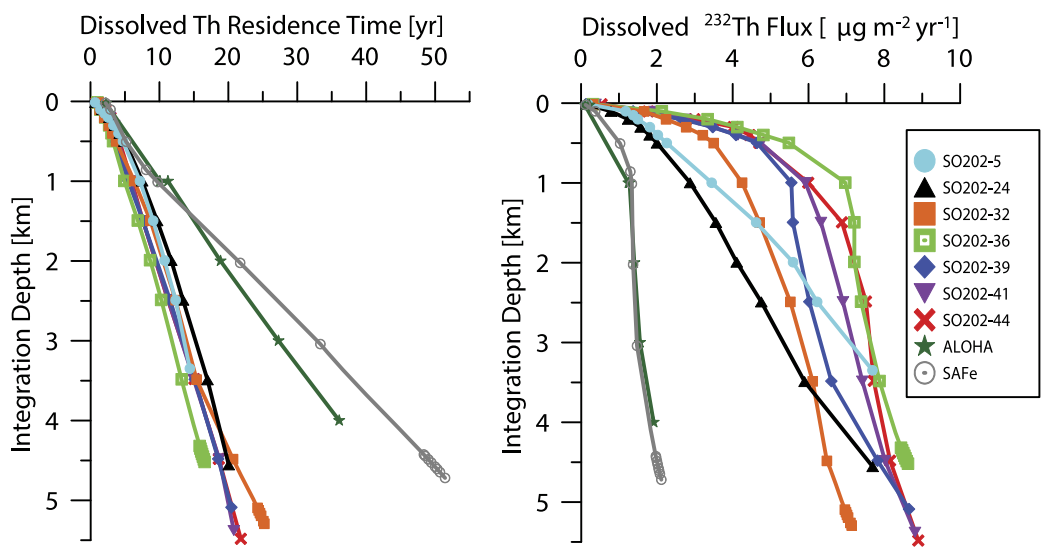

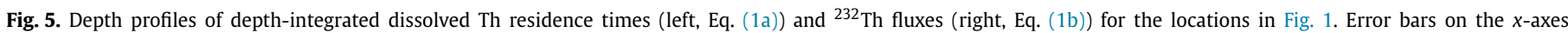

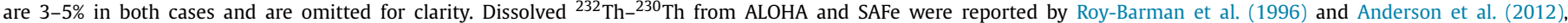
respectively.

Table 2

Apparent fractional Th solubilities derived by comparing model-derived dust deposition (Mahowald et al., 2005).

\begin{tabular}{|c|c|c|c|c|}
\hline Station & $\begin{array}{l}\text { Model dust deposition } \\
\left(\mathrm{g} \mathrm{m}^{-2} \mathrm{yr}^{-1}\right)\end{array}$ & $\begin{array}{l}S_{\mathrm{Th}} \\
(\mathrm{ML}, \%)^{\mathrm{b}}\end{array}$ & $\begin{array}{l}S_{\mathrm{Th}} \\
(500 \mathrm{~m}, \%)^{\mathrm{c}}\end{array}$ & $\begin{array}{l}\text { Dissolved Th-derived dust deposition } \\
\left(500 \mathrm{~m}, S_{\mathrm{Th}}=20 \%, \mathrm{~g} \mathrm{~m}^{-2} \mathrm{yr}^{-1}\right)\end{array}$ \\
\hline SO202-5 & $0.58 \pm 0.12$ & $3.9 \pm 1.8$ & $26.5 \pm 6.7$ & $0.77 \pm 0.20$ \\
\hline SO202-24 & $0.45 \pm 0.09$ & $8.0 \pm 2.8$ & $30.5 \pm 7.7$ & $0.69 \pm 0.17$ \\
\hline SO202-32 & $0.57 \pm 0.11$ & $9.9 \pm 2.6$ & $42.3 \pm 10.7$ & $1.20 \pm 0.30$ \\
\hline SO202-36 & $0.96 \pm 0.19$ & $5.4 \pm 2.1$ & $39.1 \pm 10.0$ & $1.88 \pm 0.48$ \\
\hline SO202-39 & $1.13 \pm 0.23$ & $1.5 \pm 0.6$ & $28.2 \pm 7.1$ & $1.59 \pm 0.40$ \\
\hline SO202-41 & $1.18 \pm 0.24$ & $4.9 \pm 1.6$ & $27.6 \pm 7.0$ & $1.62 \pm 0.41$ \\
\hline SO202-44 & $1.23 \pm 0.25$ & $5.1 \pm 1.8$ & $26.1 \pm 6.6$ & $1.61 \pm 0.41$ \\
\hline ALOHA & $0.38 \pm 0.08$ & $6.1 \pm 3.7$ & $19.1 \pm 7.6$ & $0.36 \pm 0.13$ \\
\hline SAFe & $0.45 \pm 0.09$ & $1.8 \pm 0.5$ & $15.7 \pm 4.2$ & $0.35 \pm 0.09$ \\
\hline
\end{tabular}

a Dust deposition estimates extracted from the model results of Mahowald et al. (2005), assuming 20\% uncertainty.

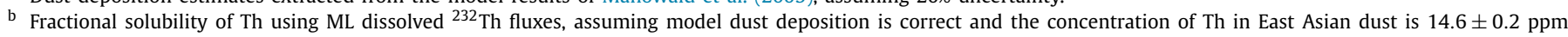
(Serno et al., submitted for publication).

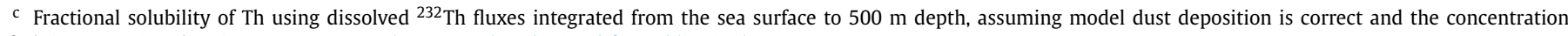
of Th in East Asian dust is $14.6 \pm 0.2 \mathrm{ppm}$ (Serno et al., submitted for publication).

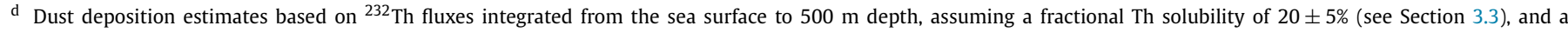
Th concentration in East Asian dust of $14.6 \pm 0.2 \mathrm{ppm}$ (Serno et al., submitted for publication).

This may need to be revised depending on the Th regeneration signals observed, seasonality in mixed layer depth, or proximity to advective/diffusive Th sources.

In order to estimate dust flux from dissolved ${ }^{232}$ Th flux, estimates of the ${ }^{232} \mathrm{Th}$ concentration in dust and the fractional solubility of Th are necessary (Eq. (1b)). Dust sources have ${ }^{232} \mathrm{Th}$ concentrations in a narrow range of the average for the upper continental crust (McGee et al., 2007). A recent study determined an end-member concentration for Th in East Asian aerosol dust of $14.6 \pm 0.2 \mathrm{ppm}$ (Serno et al., submitted for publication), making it simple to apply a [Th] litho with confidence for estimating dust fluxes (Eq. (1b)). It is possible that volcanic ash presents another eolian source of dissolved ${ }^{232} \mathrm{Th}$ to the water column. Although Th solubility of volcanic ash is not known, the Th concentration of volcanic material in marine sediments from this region is $2.2 \mathrm{ppm}$ (Serno et al., submitted for publication), much lower than that of aerosol dust, and the contribution of volcanic material to the lithogenic flux (as determined in the sediments) becomes small with distance $>500 \mathrm{~km}$ from the coast (Serno et al., submitted for publication). Contribution from volcanic ash therefore could cause a small overestimate of dust deposition at stations SO202-5 and -24 , but it is expected to be negligible at other stations.

The fractional solubility, $S_{\mathrm{Th}}$, is much more difficult to estimate with available data. Previous studies have estimated this factor in the range 1-20\% (Arraes-Mescoff et al., 2001; Hsieh et al., 2011; Roy-Barman et al., 2002). Following the approach of Hsieh et al. (2011), by fixing a [Th $]_{\text {litho, }}$, and assuming the model-derived dust deposition estimates of Mahowald et al. (2005) are correct (within
$20 \%$ uncertainty), one can use Eq. (1b) and the calculated dissolved ${ }^{232} \mathrm{Th}$ fluxes to estimate the fractional solubility. Using our mixed layer fluxes, this technique implies $S_{\mathrm{Th}}=2-10 \%$ for the INOPEX, ALOHA and SAFe sites, similar to that found by Hsieh et al., while using the 500-m fluxes we infer $S_{\mathrm{Th}}=15-40 \%$ (Table 2, Fig. 6). Increases in apparent solubility may be due to dissolution or regeneration processes occurring at depth. For instance, lithogenic particles may continue to be leached at subsurface depths by the low $\mathrm{pH}$ microenvironments associated with microbial colonies or zooplankton. However, given the refractory nature of Th, it seems unlikely that $S_{\text {Th }}$ can be as high as $40 \%$ under any oceanic conditions. We suggest that such high apparent fractional solubility indicates that the model-derived results underestimate the true dust deposition in this region, although lateral supply of sedimentary ${ }^{232}$ Th cannot be excluded entirely (Section 3.1.1).

An independent estimate of Th solubility can be derived by comparing the measured upper water column ${ }^{232} \mathrm{Th}$ flux to an annually resolved measurement of aerosol- ${ }^{232}$ Th flux on land, Mt. Haruna, Japan (Hirose et al., 2010). After correction for local sources, in 2007, the annual total ${ }^{232} \mathrm{Th}$ flux was $27.6 \mu \mathrm{g} \mathrm{m}^{-2} \mathrm{yr}^{-1}$. The nearest dissolved ${ }^{232} \mathrm{Th}$ flux (SO202-44) is $4.7 \mu \mathrm{g} \mathrm{m}^{-2} \mathrm{yr}^{-1}$, implying $17 \%$ Th solubility. We also compare our dissolved ${ }^{232} \mathrm{Th}$ fluxes to the total ${ }^{232}$ Th fluxes determined in the underlying surface sediments at the INOPEX sites. The Holocene, eolian component of sediment flux was determined with geochemical endmembers (terrigenous ${ }^{4} \mathrm{He},{ }^{232} \mathrm{Th}$, and rare earth elements) and ${ }^{230} \mathrm{Th}$-normalized burial fluxes (Serno et al., submitted for publication). The eolian- ${ }^{232}$ Th sediment fluxes compared with the $500-\mathrm{m}$ 


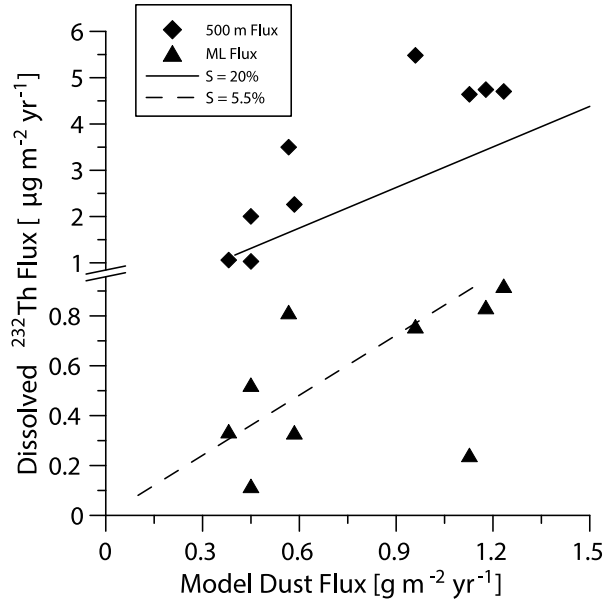

Fig. 6. Dissolved ${ }^{232} \mathrm{Th}$ fluxes as calculated for the mixed layer (triangles) and fluxes calculated by integrating Th inventories from the surface to $500 \mathrm{~m}$ depth (diamonds) from the locations in Fig. 1 against model-derived estimates of dust deposition for the same locations (Mahowald et al., 2005). The dotted and solid lines represent a constant fractional Th solubility of 5.5 and $20 \%$, respectively, both assuming a Th concentration in East Asian dust of 14.6 ppm (Serno et al., submitted for publication). Note break in $y$-axis.

dissolved ${ }^{232}$ Th fluxes indicate $S_{\mathrm{Th}}=21 \pm 11 \%$. Based on these two comparisons, we assume a fractional Th solubility of $20 \pm 5 \%$.

Our estimates of dust deposition to the North Pacific (Table 2), derived by integrating ${ }^{232} \mathrm{Th}$ inventories to $500 \mathrm{~m}$, agree with the model results (Mahowald et al., 2005) reasonably well for the subtropical sites $\left(\sim 0.4 \mathrm{~g} \mathrm{~m}^{-2} \mathrm{yr}^{-1}\right)$, while in the subarctic our estimates are 1.3-2 times higher than predicted in the model ( $\sim 1.6 \mathrm{~g} \mathrm{~m}^{-2} \mathrm{yr}^{-1}$ for SO202-36 through -44$)$. We can also compare our $500-\mathrm{m}$ dissolved ${ }^{232}$ Th-based dust estimates with the Holocene dust deposition estimates from the underlying sediment- ${ }^{232}$ Th fluxes (Serno et al., submitted for publication), while we acknowledge that both of these techniques are subject to the uncertainty of lateral ${ }^{232} \mathrm{Th}$ transport in the water column. At 4 of the 6 INOPEX sites where both water column and sediment measurements were made, dissolved ${ }^{232} \mathrm{Th}$ - and sediment ${ }^{232} \mathrm{Th}$ based dust fluxes agree within error. This is encouraging since the two techniques average over very different timescales (3-5 years in $500 \mathrm{~m}$ water depth versus thousands of years in the sediments).

Dissolved Al has also been used to estimate dust deposition in the North Pacific (Measures et al., 2005) in a similar way to that described for $\mathrm{Th}$, although for $\mathrm{Al}$, a residence time, in addition to a fractional solubility, must be assumed. These Al results from the subarctic suggest very low dust fluxes $\left(<0.3 \mathrm{~g} \mathrm{~m}^{-2} \mathrm{yr}^{-1}\right)$, even lower than model-derived estimates. We hypothesize that the assumed $\mathrm{Al}$ residence time in surface waters (5 yrs) is overestimated, especially in the more productive subarctic Pacific (Shiller and Bairamadgi, 2006).

\subsection{Dissolved metal fluxes based on dissolved ${ }^{232}$ Th fluxes}

If ${ }^{232}$ Th sources can be used as a model for other lithogenic trace metals $(\mathrm{Me})$, one can estimate the flux of metals derived from the same lithogenic source. This requires knowledge of the metal to ${ }^{232} \mathrm{Th}$ ratio of the source and the relative fractional solubility (Eq. (2)):

$$
\begin{aligned}
\text { Dissolved Me flux }= & \left(\frac{\mathrm{Me}}{232 \mathrm{Th}}\right)_{\text {litho }} \times\left(\frac{S_{\mathrm{Me}}}{S_{\mathrm{Th}}}\right) \\
& \times \text { Dissolved }^{232} \mathrm{Th} \text { flux }
\end{aligned}
$$

The relative solubility of aerosol dust is also largely unconstrained, but it is currently being pursued in the GEOTRACES pro- gram through leaching experiments (Morton et al., 2013). Relative solubilities may have an advantage over separately-determined metal solubility during leaches in that they may be less sensitive to artifacts relating to, e.g., the length of leaching, the type of leach solution or adsorption to container walls. Relative solubility may also be less sensitive to the source of dust. For instance, while fractional Fe solubility estimates range by orders of magnitude (Sholkovitz et al., 2012), the relative Fe/Th solubility may be more consistent among dust with differing source regions or atmospheric histories.

Increases in the apparent solubility when considering the longer-term processing of lithogenic particles, similar to that for Th, have been reported for Fe (Boyd et al., 2010; Frew et al., 2006; Hansard et al., 2009). On this basis, we infer a general similarity in the dissolution of relatively insoluble lithogenic elements such as $\mathrm{Fe}, \mathrm{Nd}$, etc. Assuming a $\mathrm{Fe} / \mathrm{Th}$ ratio of the average continental crust, $3262 \mathrm{gg}^{-1}$ (Taylor and McLennan, 1985), and congruent dissolution $\left(S_{\mathrm{Fe}} / S_{\mathrm{Th}}=1\right)$, the ${ }^{232} \mathrm{Th}$ flux data from the INOPEX sites around $40^{\circ} \mathrm{N}$ translates into a dissolved Fe flux due to dust dissolution of about $15 \mathrm{mg} \mathrm{Fe} \mathrm{m}^{-2} \mathrm{yr}^{-1}$. Applying our assumed $S_{\mathrm{Fe}}=20 \%$ to model estimates of natural mineral Fe deposition (Mahowald et al., 2009) gives 5-10 mg Fe $\mathrm{m}^{-2} \mathrm{yr}^{-1}$. This suggests, similar to what was concluded for dust fluxes in Section 3.3, that models currently underestimate the flux of soluble aerosol Fe, at least in the INOPEX region.

Note that the dissolved ${ }^{232} \mathrm{Th}$ flux and the ${ }^{232} \mathrm{Th}$-based dissolved Fe flux reflect the input of natural mineral aerosols. Total dissolved Fe fluxes, on the other hand, especially in a region downwind of industrial nations such as Japan and China, will likely have a significant anthropogenic component (Gao et al., 2007; Luo et al., 2008). Furthermore, volcanic ash contains little Th, but may be an important source of Fe (Duggen et al., 2010).

\subsection{Bottom water ${ }^{232}$ Th fluxes as a constraint on boundary exchange}

While depth-integrated dissolved ${ }^{232}$ Th fluxes arise primarily from the input of aerosol dust in shallow waters, additional fluxes near the seafloor appear to arise from the dissolution of postdepositional sediments (Fig. 5). This may represent the boundary exchange source of trace elements suspected to play a role for elements of paleoceanographic interest such as $\mathrm{Nd}$ and Hf (Lacan and Jeandel, 2005; van de Flierdt et al., 2004). As an attempt to quantify this source, we take the difference in integrated ${ }^{232} \mathrm{Th}$ flux between the bottom of each profile and $1 \mathrm{~km}$ depth (below which input from dust dissolution/regeneration processes attenuates). These results range from $1-5 \mu \mathrm{g}{ }^{232} \mathrm{Th} \mathrm{m}^{-2} \mathrm{yr}^{-1}$ (Fig. 5), representing $\sim 30 \%$ of the full-depth dissolved ${ }^{232} \mathrm{Th}$ flux. This probably underestimates the boundary exchange flux at SO202-5 and SO202-24 which may receive a sediment dissolution flux at all depths.

Here we also assume crustal $\mathrm{Nd} / \mathrm{Th}$ and $\mathrm{Hf} / \mathrm{Th}$ ratios of 2.4 and 0.54 , in $\mathrm{gg}^{-1}$ respectively (Taylor and McLennan, 1985), and congruent dissolution. Of course, few data exist on $\mathrm{S}_{\mathrm{Nd}}$ or $\mathrm{S}_{\mathrm{Hf}}$ to test these assumptions. A field study in the North Atlantic estimated $S_{\mathrm{Nd}}=20 \%$ (Tachikawa et al., 1999), consistent with our assumption, while experimental leaches suggest smaller values $S_{\mathrm{Nd}}=$ 1-2\% (Greaves et al., 1994) and 5-12\% (Arraes-Mescoff et al., 2001). Under our assumptions, the bottom water dissolved Th fluxes from the North Pacific sites imply bottom fluxes of $2.4-12 \mu \mathrm{g} \mathrm{m}^{-2} \mathrm{yr}^{-1}$ dissolved $\mathrm{Nd}$ and $0.5-2.7 \mu \mathrm{g} \mathrm{m}^{-2} \mathrm{yr}^{-1}$ dissolved Hf (Eq. (2)). For scale, the water column inventories ( $\sim 5 \mathrm{~km}$ depth) of dissolved $\mathrm{Nd}$ and $\mathrm{Hf}$ in the North Pacific are $26000 \mu \mathrm{g} \mathrm{m}^{-2}$ (Amakawa et al., 2009) and $2100 \mu \mathrm{g} \mathrm{m}^{-2}$ (Firdaus et al., 2011), respectively. The residence time of these elements is also still under investigation, but for purposes of illustration, let us assume $500 \mathrm{yrs}$ for both, within the range of estimated values (van de Flierdt et al., 2004). Under 
steady-state, supply and removal fluxes for the full water column cycles of $\mathrm{Nd}$ and $\mathrm{Hf}$ would then be 52 and $7.1 \mu \mathrm{g} \mathrm{m}^{-2} \mathrm{yr}^{-1}$, respectively. Therefore the boundary exchange fluxes calculated are potentially significant (10's of percent, similar to Th).

\section{Conclusions and further work}

The long-lived Th isotopes offer a unique and powerful tool to evaluate the supply of trace elements from lithogenic sources. We have identified, however, a number of sources of uncertainty that must be addressed in future studies to further refine our estimates of lithogenic fluxes. These include the lateral transport of ${ }^{232} \mathrm{Th}$ in the water column, seasonal effects of Th input and removal, the chemical speciation and size-partitioning of ${ }^{232} \mathrm{Th}$ and ${ }^{230} \mathrm{Th}$ in seawater, and fractional metal solubility.

Dissolved ${ }^{232} \mathrm{Th}$ and ${ }^{230} \mathrm{Th}$ distributions in the North Pacific demonstrate that the oceanic Th cycle is relatively simple, with two sources, including aerosol dust dissolution in shallow waters and sediment dissolution/resuspension in bottom water, and one removal mechanism, involving scavenging throughout the water column. The delivery mechanism of dissolved Th from dust dissolution, however, is relatively complex, possibly involving rapid export of colloidal Th and its subsequent regeneration or disaggregation within 500-1000 m below the sea surface. This mechanism, as well as the mechanism describing how Th is released from sediment dissolution/resuspension at the seafloor, deserves further investigation. Dissolved ${ }^{232}$ Th fluxes, nonetheless, can be applied to estimate fluxes of other lithogenically sourced dissolved trace metals (such as aerosol-derived Fe or boundary exchange-derived $\mathrm{Nd}$ or Hf), or fluxes of the parent lithogenic material (such as aerosol dust) with reasonable accuracy.

\section{Acknowledgements}

We acknowledge the German Ministry of Education and Research (BmBF) for financially supporting the SO-202-INOPEX cruise, the U.S. National Science Foundation for funding the work at L-DEO (award 1029211), and the crew of the R/V Sonne and all of the INOPEX participants for shipboard work. Natalie Mahowald is thanked for providing the model estimates of dust deposition. Comments made by Jerry McManus, Samar Khatiwala, Leo Peña, Mathieu Roy-Barman, 3 anonymous reviewers and the editor, Gideon Henderson, were helpful during the writing of the manuscript. Fig. 1 was produced using Ocean Data View (Schlitzer, 2011). This is L-DEO Contribution 7731.

\section{References}

Aguilar-Islas, A.M., Wu, J., Rember, R., Johansen, A.M., Shank, L.M., 2010. Dissolution of aerosol-derived iron in seawater: Leach solution chemistry, aerosol type, and colloidal iron fraction. Mar. Chem. 120, 25-33.

Amakawa, H., Sasaki, K., Ebihara, M., 2009. Nd isotopic composition in the central North Pacific. Geochim. Cosmochim. Acta 73, 4705-4719.

Andersen, M.B., Stirling, C.H., Zimmermann, B., Halliday, A.N., 2010. Precise determination of the open ocean ${ }^{234} \mathrm{U} /{ }^{238} \mathrm{U}$ composition. Geochem. Geophys. Geosyst. 11, Q12003.

Anderson, R.F., Fleisher, M.Q., Robinson, L.F., Edwards, R.L., Hoff, J., Moran, S.B., Rutgers van der Loeff, M.M., Thomas, A.L., Roy-Barman, M., François, R., 2012. GEOTRACES intercalibration of ${ }^{230} \mathrm{Th},{ }^{232} \mathrm{Th},{ }^{231} \mathrm{~Pa}$, and prospects for ${ }^{10} \mathrm{Be}$. Limnol. Oceanogr., Methods 10, 179-213.

Arraes-Mescoff, R., Roy-Barman, M., Coppola, L., Souhaut, M., Tachikawa, K., Jeandel, C., Sempéré, R., Yoro, C., 2001. The behavior of Al, Mn, Ba, Sr, REE and Th isotopes during in vitro degradation of large marine particles. Mar. Chem. 73, $1-19$.

Bacon, M.P., Anderson, R.F., 1982. Distribution of thorium isotopes between dissolved and particulate forms in the deep sea. J. Geophys. Res. 87, 2045-2056.

Barbeau, K., Kujawinski, E.B., Moffett, J.W., 2001. Remineralization and recycling of iron, thorium and organic carbon by heterotrophic marine protists in culture. Aquat. Microb. Ecol. 24, 69-81.
Baskaran, M., Santschi, P.H., Benoit, G., Honeyman, B.D., 1992. Scavenging of thorium isotopes by colloids in seawater of the Gulf of Mexico. Geochim. Cosmochim. Acta 56, 3375-3388.

Benitez-Nelson, C., Buesseler, K.O., Karl, D.M., Andrews, J., 2001. A time-series study of particulate matter export in the North Pacific Subtropical Gyre based on ${ }^{234} \mathrm{Th}:{ }^{238} \mathrm{U}$ disequilibrium. Deep-Sea Res., Pt. I 48, 2595-2611.

Bingham, F.M., 1992. Formation and spreading of subtropical mode water in the North Pacific. J. Geophys. Res. 97, 11177-11189.

Boyd, P.W., Mackie, D.S., Hunter, K.A., 2010. Aerosol iron deposition to the surface ocean - Modes of iron supply and biological responses. Mar. Chem. 120, 128-143.

Boyle, E.A., Bergquist, B.A., Kayser, R.A., Mahowald, N., 2005. Iron, manganese, and lead at Hawaii Ocean Time-series station ALOHA: Temporal variability and an intermediate water hydrothermal plume. Geochim. Cosmochim. Acta 69, 933-952.

Buesseler, K.O., Pike, S., Maiti, K., Lamborg, C.H., Siegel, D.A., Trull, T.W., 2009 Thorium-234 as a tracer of spatial, temporal and vertical variability in particle flux in the North Pacific. Deep-Sea Res., Pt. I 56, 1143-1167.

Charette, M.A., Breier, C.F., Henderson, P.B., Pike, S.M., Rypina, I.I., Jayne, S.R., Buesseler, K.O., 2013. Radium-based estimates of cesium isotope transport and total direct ocean discharges from the Fukushima Nuclear Power Plant accident. Biogeosciences 10, 2159-2167.

Chen, J.H., Lawrence, E.R., Wasserburg, G.J., 1986. ${ }^{238} \mathrm{U},{ }^{234} \mathrm{U}$ and ${ }^{232} \mathrm{Th}$ in seawater Earth Planet. Sci. Lett. 80, 241-251.

Chen, S., 2008. The Kuroshio extension front from satellite sea surface temperature measurements. J. Oceanogr. 64, 891-897.

Cheng, H., Edwards, R.L., Hoff, J., Gallup, C.D., Richards, D.A., Asmerom, Y., 2000. The half-lives of uranium-234 and thorium-230. Chem. Geol. 169, 17-33.

Church, M.J., Lomas, M.W., Muller-Karger, F., 2013. Sea change: Charting the course for biogeochemical ocean time-series research in a new millennium. Deep-Sea Res., Pt. II 93, 2-15.

Duce, R., Unni, C., Ray, B., Prospero, J., Merrill, J., 1980. Long-range atmospheric transport of soil dust from Asia to the tropical North Pacific: Temporal variability. Science 209, 1522-1524.

Ducet, N., Le Traon, P.Y., Reverdin, G., 2000. Global high-resolution mapping of ocean circulation from TOPEX/Poseidon and ERS-1 and -2. J. Geophys. Res. 105, 19477-19498.

Duggen, S., Olgun, N., Croot, P., Hoffmann, L., Dietze, H., Delmelle, P., Teschner, C., 2010. The role of airborne volcanic ash for the surface ocean biogeochemical iron-cycle: a review. Biogeosciences 7, 827-844.

Firdaus, M.L., Minami, T., Norisuye, K., Sohrin, Y., 2011. Strong elemental fractionation of $\mathrm{Zr}$-Hf and Nb-Ta across the Pacific Ocean. Nat. Geosci. 4, 227-230.

Frew, R., Hutchins, D., Nodder, S., Sanudo-Wilhelmy, S., Tovar-Sanchez, A., Leblanc, K. Hare, C., Boyd, P., 2006. Particulate iron dynamics during FeCycle in subantarctic waters southeast of New Zealand. Glob. Biogeochem. Cycles 20, GB1S93.

Gao, Y., Anderson, J.R., Hua, X., 2007. Dust characteristics over the North Pacific observed through shipboard measurements during the ACE-Asia experiment. Atmos. Environ. 41, 7907-7922.

Gersonde, R., 2012. The expedition of the research vessel "Sonne" to the subpolar North Pacific and the Bering Sea in 2009 (SO202-INOPEX). Rep. - Alfred Wegener Inst. Polar Mar. Res. 643, 1-323.

Greaves, M.J., Statham, P.J., Elderfield, H., 1994. Rare earth element mobilization from marine atmospheric dust into seawater. Mar. Chem. 46, 255-260.

Hanawa, K., Suga, T., 1995. A Review on the Subtropical Mode Water in the North Pacific (NPSTMW). Terra Scientific Publishing Company, Tokyo, Japan.

Hanawa, K., Talley, L.D., 2001. Mode waters. In: Siedler, G., Church, J., Gould, J. (Eds.), Ocean Circulation and Climate: International Geophysics Series. Academic Press, pp. 373-386.

Hansard, S.P., Landing, W.M., Measures, C.I., Voelker, B.M., 2009. Dissolved iron(II) in the Pacific Ocean: Measurements from the PO2 and P16N CLIVAR/CO2 repeat hydrography expeditions. Deep-Sea Res., Pt. I 56, 1117-1129.

Harrison, P., Whitney, F., Tsuda, A., Saito, H., Tadokoro, K., 2004. Nutrient and plankton dynamics in the NE and NW gyres of the Subarctic Pacific Ocean. J. Oceanogr. 60, 93-117.

Hayes, C.T., Anderson, R.F., Jaccard, S.L., François, R., Fleisher, M.Q., Soon, M., Gersonde, R., 2013. A new perspective on boundary scavenging in the North Pacific Ocean. Earth Planet. Sci. Lett. 369-370, 86-97.

Hirose, K., Sugimura, Y., 1987. Thorium isotopes in the surface air of the Western North Pacific Ocean. J. Environ. Radioact. 5, 459-475.

Hirose, K., Igarashi, Y., Aoyama, M., Inomata, Y., 2010. Depositional behaviors of plutonium and thorium isotopes at Tsukuba and Mt. Haruna in Japan indicate the sources of atmospheric dust. J. Environ. Radioact. 101, 106-112.

Hirose, K., Kikawada, Y., Igarashi, Y., 2012. Temporal variation and provenance of thorium deposition observed at Tsukuba, Japan. J. Environ. Radioact. 108, 24-28.

Holden, N.E., 1990. Total half-lives for selected nuclides. Pure Appl. Chem. 62, 941-958.

Hsieh, Y.-T., Henderson, G.M., Thomas, A.L., 2011. Combining seawater ${ }^{232}$ Th and ${ }^{230} \mathrm{Th}$ concentrations to determine dust fluxes to the surface ocean. Earth Planet. Sci. Lett. 312, 280-290. 
Huh, C.-A., Moore, W.S., David, C.K., 1989. Oceanic ${ }^{232}$ Th: A reconnaissance and implications of global distribution from manganese nodules. Geochim. Cosmochim. Acta 53, 1357-1366.

Iwao, T., Endoh, M., Shikama, N., Nakano, T., 2003. Intermediate circulation in the northwestern North Pacific derived from subsurface floats. J. Oceanogr. 59, 893-904.

Johnson, K.S., Elrod, V.A., Fitzwater, S.E., Plant, J.N., Chavez, F.P., Tanner, S.J., Gordon, R.M., Westphal, D.L., Perry, K.D., Wu, J., Karl, D.M., 2003. Surface ocean-lower atmosphere interactions in the Northeast Pacific Ocean Gyre: Aerosols, iron, and the ecosystem response. Glob. Biogeochem. Cycles 17, 1063.

Kawabe, M., 2008. Vertical and horizontal eddy diffusivities and oxygen dissipation rate in the subtropical Northwest Pacific. Deep-Sea Res., Pt. I 55, 247-260.

Kawakami, H., Honda, M.C., 2007. Time-series observation of POC fluxes estimated from ${ }^{234} \mathrm{Th}$ in the northwestern North Pacific. Deep-Sea Res., Pt. I 54, $1070-1090$

Lacan, F., Jeandel, C., 2005. Neodymium isotopes as a new tool for quantifying exchange fluxes at the continent-ocean interface. Earth Planet. Sci. Lett. 232, 245-257.

Levitus, S., 1982. Climatological Atlas of the World Ocean. NOAA Prof. Paper. U.S. Govt. Print. Off., Washington, DC, p. 173.

Li, Y.-H., Feely, H.W., Toggweiler, J.R., $1980 .{ }^{228} \mathrm{Ra}$ and ${ }^{228} \mathrm{Th}$ concentrations in GEOSECS Atlantic surface waters. Deep-Sea Res., Pt. A 27, 545-555.

Luo, C., Mahowald, N., Bond, T., Chuang, P.Y., Artaxo, P., Siefert, R., Chen, Y., Schauer J., 2008. Combustion iron distribution and deposition. Glob. Biogeochem. $\mathrm{Cy}-$ cles 22, GB1012.

Luo, S., Ku, T.-L., Kusakabe, M., Bishop, J.K.B., Yang, Y.-L., 1995. Tracing particle cycling in the upper ocean with ${ }^{230} \mathrm{Th}$ and ${ }^{228} \mathrm{Th}$ : An investigation in the equatorial Pacific along $140^{\circ} \mathrm{W}$. Deep-Sea Res., Pt. II 42, 805-829.

Mahowald, N.M., Baker, A.R., Bergametti, G., Brooks, N., Duce, R.A., Jickells, T.D., Kubilay, N., Prospero, J.M., Tegen, I., 2005. Atmospheric global dust cycle and iron inputs to the ocean. Glob. Biogeochem. Cycles 19, GB4025.

Mahowald, N.M., Engelstaedter, S., Luo, C., Sealy, A., Artaxo, P., Benitez-Nelson, C., Bonnet, S., Chen, Y., Chuang, P.Y., Cohen, D.D., 2009. Atmospheric iron deposition: Global distribution, variability, and human perturbations. Ann. Rev. Mar. Sci. 1, 245-278.

Maiti, K., Benitez-Nelson, C.R., Buesseler, K.O., 2010. Insights into particle formation and remineralization using the short-lived radionuclide, Thorium-234. Geophys. Res. Lett. 37, L15608.

Marchal, O., Lam, P.J., 2012. What can paired measurements of Th isotope activity and particle concentration tell us about particle cycling in the ocean?. Geochim. Cosmochim. Acta 90, 126-148.

Martin, J.H., Gordon, M.R., 1988. Northeast Pacific iron distributions in relation to phytoplankton productivity. Deep-Sea Res., Pt. A 35, 177-196.

McGee, D., Marcantonio, F., Lynch-Stieglitz, J., 2007. Deglacial changes in dust flux in the eastern equatorial Pacific. Earth Planet. Sci. Lett. 257, 215-230.

Measures, C.I., Brown, E.T., 1996. Estimating dust input to the Atlantic Ocean using surface water Al concentrations. In: Guerezoni, S., Chester, R. (Eds.), The Impact of Desert Dust Across the Mediterranean. Kluwer, Boston, pp. 305-315.

Measures, C.I., Brown, M.T., Vink, S., 2005. Dust deposition to the surface waters of the western and central North Pacific inferred from surface water dissolved aluminum concentrations. Geochem. Geophys. Geosyst. 6, Q09M03.

Measures, C.I., Cutter, G.A., Landing, W.M., Powell, R.T., 2006. Hydrographic observations during the 2002 IOC contaminant baseline survey in the western Pacific Ocean. Geochem. Geophys. Geosyst. 7, Q03M06.

Moore, W.S., 2000. Determining coastal mixing rates using radium isotopes. Cont. Shelf Res. 20, 1993-2007.

Moore, W.S., Sackett, W.M., 1964. Uranium and thorium series inequilibrium in sea water. J. Geophys. Res. 69, 5401-5405.

Moran, S.B., Buesseler, K.O., 1992. Short residence time of colloids in the upper ocean estimated from ${ }^{238} \mathrm{U}{ }^{234} \mathrm{Th}$ disequilibria. Nature $359,221-223$.

Morton, P.L., 2010. Trace metal biogeochemistry in the western North Pacific. PhD Dissert. Old Dominion University, Norfolk, VA.

Morton, P.L., Landing, W.M., Hsu, S.-C., Milne, A., Aguilar-Islas, A.M., Baker, A.R., Bowie, A.R., Buck, C.S., Gao, Y., Gichuki, S., Hastings, M.G., Hatta, M., Johansen, A.M., Losno, R., Mead, C., Patay, M.D., Swarr, G., Vendermark, A., Zamora, L.M. 2013. Methods for sampling and analysis of marine aerosols: results from the 2008 GEOTRACES aerosol intercalibration experiment. Limnol. Oceanogr., Methods $11,62-78$.
Nozaki, Y., Horibe, Y., 1983. Alpha-emitting thorium isotopes in northwest Pacific deep waters. Earth Planet. Sci. Lett. 65, 39-50.

Nozaki, Y., Nakanishi, T., $1985 .{ }^{231} \mathrm{~Pa}$ and ${ }^{230} \mathrm{Th}$ profiles in the open ocean water column. Deep-Sea Res., Pt. A 32, 1209-1220.

Nozaki, Y., Horibe, Y., Tsubota, H., 1981. The water column distributions of thorium isotopes in the western North Pacific. Earth Planet. Sci. Lett. 54, 203-216.

Nozaki, Y., Yang, H.-S., Yamada, M., 1987. Scavenging of thorium in the Ocean. J. Geophys. Res. 92, 772-778.

Ohno, Y., Iwasaka, N., Kobashi, F., Sato, Y., 2009. Mixed layer depth climatology of the North Pacific based on Argo observations. J. Oceanogr. 65, 1-16.

Oka, E., Talley, L.D., Suga, T., 2007. Temporal variability of winter mixed layer in the mid-to high-latitude North Pacific. J. Oceanogr. 63, 293-307.

Oka, E., Kouketsu, S., Toyama, K., Uehara, K., Kobayashi, T., Hosoda, S., Suga, T., 2011. Formation and subduction of central mode water based on profiling float data, 2003-08. J. Phys. Oceanogr. 41, 113-129.

Okubo, A., Obata, H., Gamo, T., Yamada, M., 2012. ${ }^{230}$ Th and ${ }^{232}$ Th distributions in mid-latitudes of the North Pacific Ocean: Effect of bottom scavenging. Earth Planet. Sci. Lett. 339-340, 139-150.

Orians, K.J., Bruland, K.W., 1986. The biogeochemistry of aluminum in the Pacific Ocean. Earth Planet. Sci. Lett. 78, 397-410.

Owens, W.B., Warren, B.A., 2001. Deep circulation in the northwest corner of the Pacific Ocean. Deep-Sea Res., Pt. I 48, 959-993.

Parrington, J.R., Zoller, W.H., Aras, N.K., 1983. Asian dust: Seasonal transport to the Hawaiian Islands. Science 220, 195-197.

Rea, D.K., 1994. The paleoclimatic record provided by eolian deposition in the deep sea: The geologic history of wind. Rev. Geophys. 32, 159-195.

Roy-Barman, M., 2009. Modelling the effect of boundary scavenging on thorium and protactinium profiles in the ocean. Biogeosciences 6, 3091-3197.

Roy-Barman, M., Chen, J.H., Wasserburg, G.J., 1996. ${ }^{230} \mathrm{Th}-{ }^{232}$ Th systematics in the central Pacific Ocean: The sources and the fates of thorium. Earth Planet. Sci. Lett. 139, 351-363.

Roy-Barman, M., Coppola, L., Souhaut, M., 2002. Thorium isotopes in the western Mediterranean Sea: an insight into the marine particle dynamics. Earth Planet. Sci. Lett. 196, 161-174.

Roy-Barman, M., Lemaître, C., Ayrault, S., Jeandel, C., Souhaut, M., Miquel, J.C., 2009. The influence of particle composition on thorium scavenging in the Mediterranean Sea. Earth Planet. Sci. Lett. 286, 526-534.

Santschi, P.H., Murray, J.W., Baskaran, M., Benitez-Nelson, C.R., Guo, L.D., Hung, C.C., Lamborg, C., Moran, S.B., Passow, U., Roy-Barman, M., 2006. Thorium speciation in seawater. Mar. Chem. 100, 250-268.

Schlitzer, R., 2011. http://odv.awi.de.

Serno, S., Winckler, G., Anderson, R.F., Hayes, C.T., McGee, D., Machalett, B., Ren, H., Straub, S.M., Gersonde, R., Haug, G.H., submitted for publication. Eolian dust input to the Subarctic North Pacific. Earth Planet. Sci. Lett.

Shiller, A.M., Bairamadgi, G.R., 2006. Dissolved gallium in the northwest Pacific and the south and central Atlantic Oceans: Implications for aeolian Fe input and a reconsideration of profiles. Geochem. Geophys. Geosyst. 7, Q08M09.

Sholkovitz, E.R., Sedwick, P.N., Church, T.M., Baker, A.R., Powell, C.F., 2012. Fractional solubility of aerosol iron: Synthesis of a global-scale data set. Geochim. Cosmochim. Acta 89, 173-189.

Singh, A.K., Marcantonio, F., Lyle, M., 2013. Water column ${ }^{230}$ Th systematics in the eastern equatorial Pacific Ocean and implications for sediment focusing. Earth Planet. Sci. Lett. 362, 294-304.

Suga, T., Motoki, K., Aoki, Y., Macdonald, A.M., 2004. The North Pacific climatology of winter mixed layer and mode waters. J. Phys. Oceanogr. 34, 3-22.

Tachikawa, K., Jeandel, C., Roy-Barman, M., 1999. A new approach to the Nd residence time in the ocean: the role of atmospheric inputs. Earth Planet. Sci. Lett. $170,433-446$

Talley, L.D., 1993. Distribution and formation of North Pacific intermediate water. J. Phys. Oceanogr. 23, 517-537.

Taylor, S.R., McLennan, S.M., 1985. The Continental Crust: Its Composition and Evolution. Blackwell, Oxford.

van de Flierdt, T., Frank, M., Lee, D.-C., Halliday, A.N., Reynolds, B.C., Hein, J.R., 2004. New constraints on the sources and behavior of neodymium and hafnium in seawater from Pacific Ocean ferromanganese crusts. Geochim. Cosmochim. Acta $68,3827-3843$ 